\title{
Masculinity and Family Bonding in Naguib Mahfouz's Palace Walk and Eudora Welty's Delta Wedding.
}

\author{
Dr. Shaimaa Mohamed Hassanin \\ Lecturer of English Literature \\ Department of Basic Sciences \\ Faculty of Physical Therapy, Horus University- Egypt
}

\begin{abstract}
:
This paper investigates the ambivalence of masculinity in Eudora Welty's Delta Wedding (1946) and Naguib Mahfouz's Palace Walk (1956). Welty and Mahfouz's writings are social presentations of their countries' history and culture. As for Welty's writings, they have been often read as feminist interrogations of history. This paper contends that Delta Wedding and Palace Walk should be examined as tales of the nature of masculinity in some countries. Masculinity in their writings is questioned and subverted; masculinity, rather than being settled, normal, and heroic is here uncovered as harsh, promptly imitated, limited to outer shapes and appearances. Welty and Mahfouz employ the fictionality of masculinity to uncover different behaviors of men represented in Fairchild and Ahmed Abdulgawad. In addition, this paper examines the impact of war on the life style delineated in Eudora Welty's Delta Wedding (1946) and Naguib Mahfouz's Palace Walk (1956). The present paper centers on female characters who adjust to the absence of their husbands, whether because of wars or because of their self- centered behaviors. Wars are the catalyst for societal change within the novels, and women must adopt to the new social changes that are infringing upon their lives. The paper explores each person's reaction of particular female characters within the novels. The female characters in Delta Wedding speak in different ways of responding to the changeable social standards brought usually by war and societal standards imposed by individuals. As for Mahfouz's Palace Walk, female characters are kept silent, because of their fear of being recognized as rebels by their husbands or parents.
\end{abstract}

Key words: Masculinity, Family, Welty, Mahfouz, Female, Society standards. 


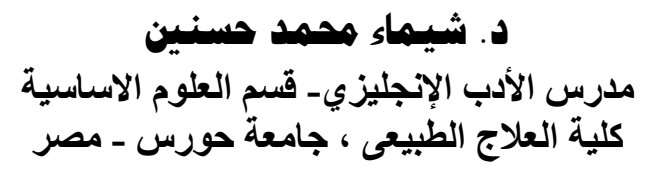

ملغص البحث

تبحث هذه الورقة في تناقض الذكورة في عرس دلتا ليودورا ويلتي (7؟9 19) وبين

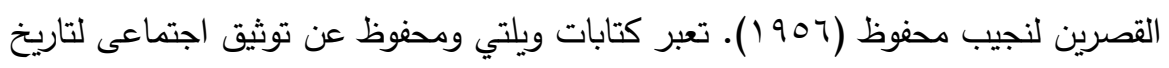

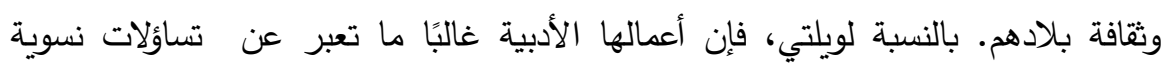

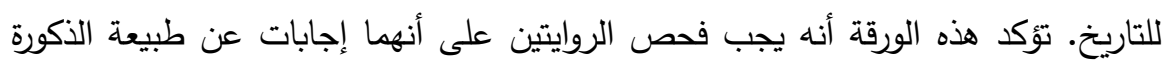

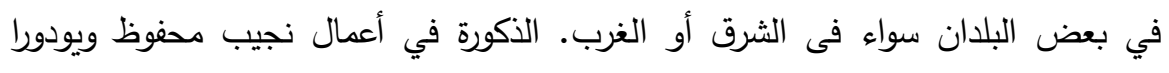

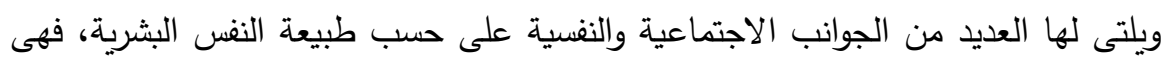

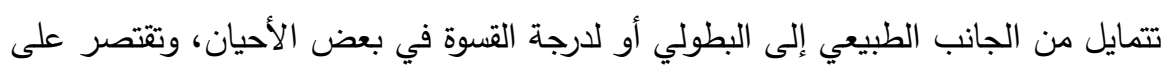

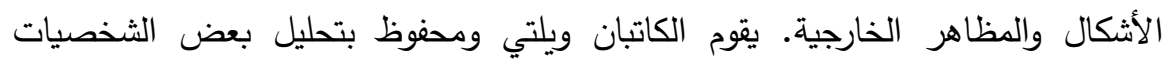

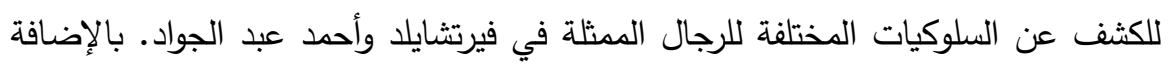

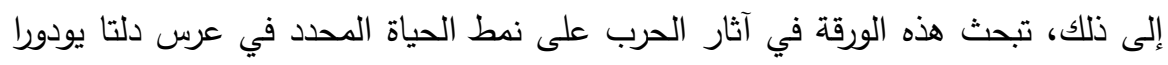

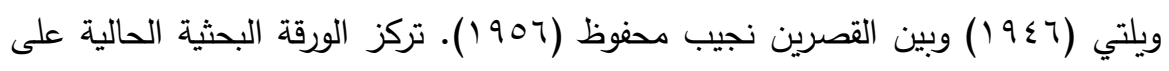

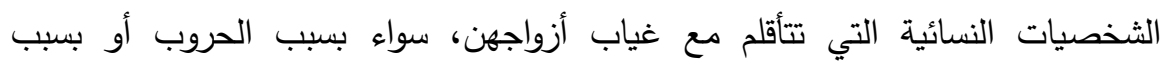

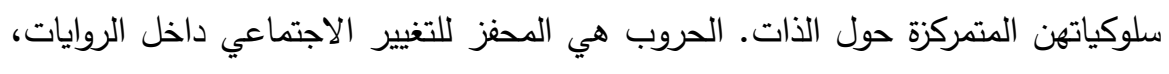

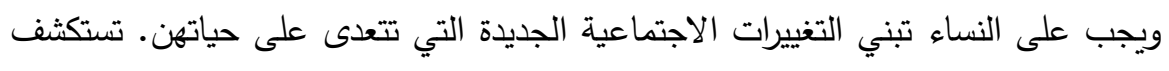

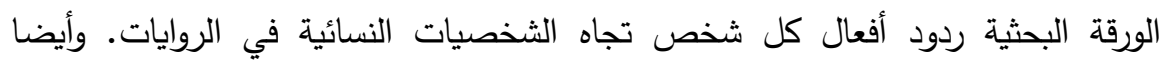

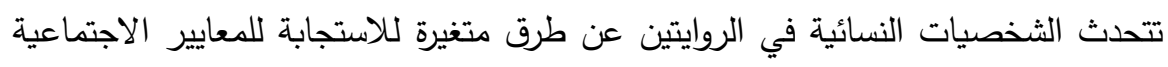

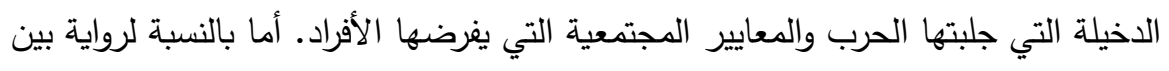

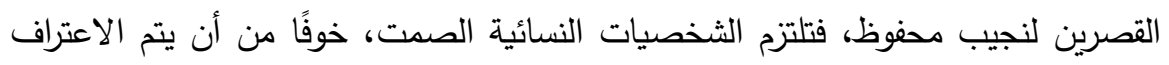

$$
\text { على أنهن نساء متمردات. }
$$

الكلمات المفتاحية: الذكورة، الأسرة، ويلتي، محفوظ، أنثى، معايير المجتمع. 
Masculinity and Family Bonding in Naguib Mahfouz's Palace Walk and Eudora Welty's Delta Wedding.

Dr. Shaimaa Mohamed Hassanin

مجلة وادي النيل للاراسات والبحوث الإنسانية والاجتماعية والتربوية (مجلة علمية محكمة)

\section{Masculinity and Family Bonding in Naguib Mahfouz's Palace Walk and Eudora Welty's Delta Wedding.}

\section{Introduction:}

Family bonding is a notion that societies are trying to define and explore its real nature, and give it a new coinage to help restore the family interconnections. An analysis of what family means to its individuals should consider all the factors that influence its structure. A family is a part of the society and an essential part in the life of its individuals; it represents the social nucleus by which every member can gain the societal impact. Through the selected novels Delta Wedding and Palace Walk, Mahfouz and Welty are trying to set the main codes of families in their societies. These codes may vary from one society to another, but the main ethics remain the same through ages. Through breaking the family codes, individuals may suffer, and this may change their way of thinking that may lead the rapid change of the family codes in the societies.

Palace Walk, the first novel in Mahfouz's trilogy, opens at the beginning of WWI and marks the foremost brutal period of Egypt's colonial history. The three novels together explore Egypt's development from British protectorate to an independent state. The geographical shifts give the driving force well-known social changes, counting the return of Salafi Islam and the recharging Islamic basic to shroud, which are the foci of proposition. As the socio-political issues give the roots of man's presence for Mahfouz, this paper seeks to analyze the socio-political shifts behind the changed hone of veiling in Egypt through Mahfouz's novel as a source of Egyptian social history. Mahfouz, hence, assumes the role of both a critic and a chronicler in Palace Walk: "Perhaps it is this atmosphere, which my generation imbibed, that makes it particularly painful for us to witness the growth of religious fanaticism. For us it is an alien phenomenon, and any harm inflicted on our Coptic brothers is inflicted on us all. (Mahfouz, 2001, p.108) 
(ISSN : 2536 - 9555)

Like several good weddings, Eudora Welty's Delta Wedding (1946) "showcases the women" at the center of the incidents, depicts the lives of a Mississippi Delta family in 1923 as they get ready for the wedding of Dabney, their eldest daughter and Troy Flavin, "the outsider, working-class Fairchild overseer" (Tipton, p.112). Welty has undoubtedly "put the women and their thoughts and perceptions in the foreground of her novel" (Powell, 2007, p.49). Not shockingly, most faultfinders have lauded Delta Wedding for its story structure which resists "traditional masculine narrative by providing women with a voice," and for its depiction of "the multiplicity of white Southern femininity [that gives] a voice to several different types of women" (Wallace 2009, p.1). Susan V. Donaldson, in specific, contends that the novel ought to be perused as a "feminist interrogation of history and historical perspective" (Donaldson, 1997, p. 3), because Welty offers a "matriarchal world" (Donaldson, 1997, p. 5) - a feminine South if you will — and maybe most importantly, an "oddly inverted heroic narrative" (Donaldson, 1997, p. 5), one in which the author explores a "confrontation with" and reformulation of "patriarchal myths and masculinist texts" (Wallace, 2009, p. 3).

\section{Importance of the study:}

From a social perspective, this paper attempts to analyze the two novels written by Naguib Mahfouz and Eudora Welty within the theoretical framework of social reading to highlight how the society can impose strict standards on its individuals. In addition, the society traditions and family code can be altered through ages due to the rapid change of the individuals within the society. live has become rapid, most people cannot follow this change; so, they struggle to reach their goals. On their way to achieve their dreams, their personalities can change and face a problem of facing the new standards of the society. through the two novels, Mahfouz and Welty try to show the codes of different societies in the opening of the twentieth century. 
مجلة وادي النيل للاراسات والبحوث الإنسانية والاجتماعية والتربوية (مجلة علمية محكمة)

\section{Aims of the Study:}

The literary works of Mahfouz and Welty hold a special position in Arabic and English writings. As for Mahfouz, Palace Walk tries to define the history of the country through an Egyptian family. The family's individuals are characterized professionally to show the history of Egypt in the beginning of the twentieth century. As for Delta Wedding, Welty tries to draw her character to show them as the real motivators of the changing standards of the society. This paper tries to prove that the family codes are objected to many threats that try to change the main structure of the society. It also tries to show how that change has affected the individuals and urged them to change their behaviors to cope up with the new standards imposed by other members of their society.

\section{Theory and Method:}

The existential approach is used in the paper, as it goes beyond the regular meaning of common sense or everyday situations. Many individuals accept the idea of taking place in the world, some other think that they came to the world for a purpose that they can accomplish. This variety of individuals creates a different atmosphere that helps improve the society. Individuals' endeavors to change the society may be faced with aggressive behaviors from others. The existential approach is an endeavor to delve into the world by arranging the occasions in their comparing environment (i.e., social structure, culture, history) and attempting to obtain its behaviors by collecting and analyzing the available information.

The existential approach is a philosophical one. It is concerned with understanding people's position in the world and with the clarification of what it implies to be lively. It is concerned with exploring some questions with a receptive attitude, instead of unyielding them. It tries to search for truth with an open intellect and a demeanor of thinking, not fitting of the client into preestablished categories and elucidations. For the existential 
approach, the human nature is an open- ended one, adaptable and able of a colossal run of encounter. The individual is in a consistent readiness of every situation. There's no fundamental, strong self, no definition of one's identity and capacities.

\section{Discussion:}

Palace Walk and Delta Wedding discuss how to deal with the family from different perspectives as well as different cultures. As for Naguib Mahfouz's novel, it deals with the family from the point of view of the control father; even though there is a hidden side in his life that no one knows anything about. This aspect is the cause of the misery and unhappiness of the family. It shows that the protagonist wants to hide something from everyone, and treat his family strictly and exaggeratedly. But at the same time, he is trying to bring the family together and always try to reunite them. Despite the children's rebellion and desperate attempts to distance themselves from their father's control, they are close and support each other at all time. On the other hand, in Welty's novel, the writer tries to keep the family together at the wedding that all family members will meet in an attempt to communicate. The two novels' main concern was the family and how to survive and preserve its heritage; thus preserving society, its cultural and social entity.

Palace Walk, the first novel of the trilogy, refers to the generation of Abd Al-Jawad's family from 1917, the date which marks the opening of the novel. Palace Walk, in spite of its publication in 1956, records the lives of the primary era of Abdulgawad in WWI Cairo. It is basically through the family patriarch, Al-Sayyid Ahmed, that we come to know the other guideline characters within the novel. In fact, most of the struggles that the characters suffer are due to their trials to live under the dictatorship of Ahmed, following his rules. Al-Sayyid Ahmad a 45-year-old merchant and patriarch is best characterized by his inconsistencies instead of positive properties. Among his family, Al-Sayyid Ahmed is strict, dictator and much dreaded by both his wife and children. However, at his shop and amid his 
مجلة وادي النيل للاراسات والبحوث الإنسانية والاجتماعية والتربوية (مجلة علمية محكمة)

evening amusements, Al-Sayyid Ahmed completely changes among his companions and clients seeking his liberality; he is wellknown among the ladies for his sexual ability. When the novel opens, Al-Sayyid Ahmed has just finished an affair with the singer Jalila, to start a new one with another female performer named Zubaida. At home, in spite of the fact that Al-Sayyid Ahmed's family knows him only as a devout Muslim and a strict person.

Al-Sayyid Ahmed is the father of Yassin (21) from a previous marriage, Khadija (20), Fahmy (18), Aisha (16) and Kammal (10). At the beginning of the novel, the reader notices that Al-Sayyid Ahmed has been married to Amina for about 25 years. Their marriage is a normal middle-class patriarchal control, more than a love union. Concurring to middle-class Egyptian traditions at this time, a man's wife and children are respected due to their father's reputation. They carry his title and share his wealth after his death. Yassin is Al-Sayyid Ahmed eldest son and, in numerous ways, his twofold, Yassin is characterized by aggressive manners and animalistic appetite. Like his father, Yassin enjoys drinking alcohol late at night and is accompanied by women. These points of interest are deeply inherited from his father.

On the other hand, in Delta Wedding, Welty's perusing of the novel's women's activist across examination of history stands to reasons: in this shielded community of the Fairchild, the incredible close relatives, war dowagers like close relative Shannon and close relative Mac, have certainly ended up the "matriarchs of the clan" and "their governance of the Fairchild family has resulted in an interesting internal power structure that privileges females" (Miller, 2004, p. 55). Nevertheless, when managing with sex in the novel, one ought to notice Welty's use of words of caution. Welty frequently communicated her hesitance at being labeled a "woman writer" or as a "feminist"-going as far as telling Charles Bunting in 1972 that she was "not interested in any kind of feminine repartee" (Prenshaw, 1979, p. 54). The attention is given to the woman's address in Delta Wedding ought to not cloud the reality 
that the novel is likely to begin with the preeminent, what Brinkmeyer has characterized as the representation of a Southern family myth that "has the male hero [George Fairchild] at its focus" (qtd. in Bouton, 2008, p. 93).

Because of the attention given to the woman's problem in Delta Wedding, the novel appears to offer less the feminist's activist creation of a protective world than the women's activist creation of a certain sort of masculine heroism that itself can be imagined as another oddly- inverted courageous account. Even if "the family's concern is [certainly] fueled in part by hero worship, for George and his fellow Fairchild men" (Donaldson, 1997, p. 4), one may inquire: what makes George this perfect man, the one who has cherished best? "Lover and protector and dreaming, forgetful conscience" (Donaldson, 1997, p. 280)? What undoubtedly might bring, to utilize Brinkmeyer's detailing, the male hero at the center of this Southern family myth? Delta Wedding clears out these unanswered questions.

As for Palace Walk, Yassin can be said to be Al-Sayyid Ahmed's rough-edged doppelganger, Fahmy is Al-Sayyid Ahmed's mental side. Fahmy is a genuine law-student with a dreamy vision who seeks the rights of his countries without being immersed in amusements, unlike his father or brother. In addition, Fahmy is ghastly anxious of his father and is closely tolerated by al-Sayyid Ahmad's code of middle-class conduct. When Fahmy inquires and is denied authorization to be engaged the neighbor's girl, Maryam, he felt ignored and lost his selfconfidence. In such manner, it takes an occasion of amazing significance for Fahmy to break his father's bonding. At the end of the novel, Fahmy takes an interest in a well- known anti-British rally against al-Sayyid Ahmad's wishes. It is within the course of this fizzled challenge that Fahmy is shot and slaughtered. With Fahmy, at that point, the pride and trust of Al-Sayyid Ahmad too is shoot and killed. By the death of Fahmy, the pride and hope of AlSayyid Ahmed has died too: 'I ask about your future," his father cries out, "and you reply that you want to know the origin of life 
and its destiny. What will you do with that? Open a booth as a fortuneteller?" (Dryer, 1991, p. 70)

The novels express the writers' farsightedness, as if they predicted the inevitable fate of humanity, which became clearer in the twenty-first century through the Corona virus, which forced us to social distance from the family and its members. The narrations are thus an alarm guiding us to the need to preserve the family entity. Welty's indecision almost sexual orientation has gotten away the basic look of most researchers. Analysis of the woman's address in Delta Wedding have investigated a correspondence between Welty and women's activists who examine sexual orientation character and see sexual orientation as liquid, as contradicted to a given fixity-foundation of the mastery of the "heterosexual matrix" to utilize Judith Butler's term. In specific, Welty's treatment of the woman/ wedding issue in this shielded South of the Delta encourages the unsetting of the conventional verifiable viewpoints on sex. As Elizabeth Crews clarifies, there's in Delta Wedding a fluidity of sexual orientation that's encouraged by mutual misunderstanding, "not all adults in the novel agree on what constitutes socially accepted gender roles" (Crews, 2012, p. 62). What is more, "not as it were are there contrasting sees among the characters on the part of sexual orientation in Delta society, there are too contrasting sees on the ways in which sex parts characterize the Fairchilds" (Crews, 2012, p. 64). The coming about impact is one of significant insecurity. As Crews comments, "Troy feels that a woman's place is in the home doing tasks necessary for comfort and survival. Tempe counters Troy's idea. She tells Dabney not to let Troy know she can cook in order to avoid having to cook for the rest of her life" (Crews, 2012, p. 62). Welty in this way guarantees different opening for sex inconvenience, that is for undermining "masculine and feminine categories taken to be foundational and unchanging" (Donaldson, 1997, p. 11). 
(ISSN : 2536 - 9555)

Delta Wedding, be that as it may, falls brief of its starting guarantee. On the off chance that the story certainly depicts the Fairchild ladies who have long dwarfed the male individuals of the family and who have learnt how to utilize what Robbie Reid names the "pleading mask" that permits them to urge it all and in particular, "everything that may well be given-all anxiety and masculine care" (Welty, 1998, p.236), such ease is closely kept to the Delta. If the men within the novel can be seen as unimportant "figureheads who taste the wishes of their women" (Miller, 2004, p. 58), Laura realizes that "it was the boys and the men that characterized the family continuously. All the young ladies knew it" (Welty, 1998, p.102).

Eventually, Delta Wedding clears out a blended commitment to the revisionary readings of the ladylike South in her fiction: in fact, no matter how engaging, such readings of the Southern lady perfect smash the establishments of the hegemonic patriarchal arrange. As one of Delta Wedding's female characters recognizes, "it was notoriously the women of the Fairchilds who since the Civil War, or-who knew? -since the Indian times, ran the household and had everything at their fingertips-not the men. The women it was who inherited the place-or their brothers, guiltily, handed it over" (Welty,1998, p. 234). As Pearl McHaney recognizes, indeed in the event that Dabney for occurrence challenges the social codes of her family, she does not conceive of herself as advancing, of moving past the boundaries of the Delta world. She does not set herself as making a modern framework image either for herself or for her sisters or for other ladies. "She does not conceive of changing the sex parts of the men or of the ladies of the Delta. For all of her protestations and willfulness, she does remain within the Delta, tied to the arrive." (McHaney, 2005, p.139)

Examined in this light, Welty's intrigued is in destabilizing the "heterosexual matrix" that manages a few settled parts to men and ladies within the title of sexual orientation, Welty does not propose a remaking of gender along modern lines. She falls 
مجلة وادي النيل للاراسات والبحوث الإنسانية والاجتماعية والتربوية (مجلة علمية محكمة)

flat to advance a re-conception of the woman's put or a recharged perfect of femininity the fundamental reason being the failure of these ladies to elude the fixity of sexual orientation traditions. Moreover, these ladies are settled, since they have denied to move from the Delta and step absent from their assigned roles as supporters of those who are dynamic and doers, the men. On that point particularly, Elizabeth Crews reminds us that "the Fairchild men (Denis and George specifically) are the ones venerated and worshiped, not the women" (Crews, 2012, p. 64).

According to Richard Dyer in his review of Palace Walk, Kammal "is both the portrait of the artist as a young man, Naguib Mahfouz himself, and the representative of a new and uncolonial Egypt. 'I ask about your future," his father cries out, "and you reply that you want to know the origin of life and its destiny. What will you do with that? Open a booth as a fortuneteller?" (Dryer, 1991, p. 70) In Palace Walk, Kammal remains securely hidden inside the female space of family domestic, limited inside the system of Egypt's middle-class traditions. In many scenes, Kammal is the sole male companion of his mother and sisters, sitting with them as they prepare or lock in within the most recent gossip. Indeed, it is often through Kammal's guiltless and, as however, untainted relationship to the ladies within the family that we are ready to induce a boarder of their characters exterior to their parts as workers and servants.

While the male characters are allowed a bit of flexibility from the control and observation of the father, the female characters in Palace Walk never stray distant from his shadow. Amina, AlSayyid Ahmed's wife, shows up quiet and easygoing following her husband the essential setting in which readers regularly see her. No doubt, Amina in her devotion and unquestioning compliance to her husband, is in insignis of Egyptian traditions. As such, Amina could be a source of solidness, her picture all through the novel typifying the esteem framework that outlines the novel itself. 
This can be particularly passed on through her relationship to Al-Sayyid Ahmad, or, more precisely, through his control over her. From this viewpoint, one of the ways in which Delta Wedding contains the ease of womanliness circulating through the content is by coordinating all account endeavors to the male figure that comes center stage. Clearly sufficient, what brings the male saint at the center of the account is to begin with and preeminent a gendered center given to George. The portrayal shifts among different female characters' perspectives. Manly subjectivity is caught up in ladies looking at men, for it is ladies who are basically the ones in charge of characterizing what and who George and Denis their sparkling heroes are.

Within the introduction of the male saint, the reader witnesses the generation of a perfect of manliness given as visual delight. Dabney realizes that "it was Denis and always would be Denis that they gave the family honor to . . . Denis was the one that looked like a Greek God ... squandered away his life loving people too much, [and] was too kind to his family. .." (Welty, 1998, p. 205). Since Denis passes on, another brother must end up the family saint, and George Fairchild is the one filling up this part. Within the depiction of George, the focus is the male personality connected to the heroic notion of manliness, and ladies are included within the situation as those who voice the bravery. Wendy Pearce Mill fairly comments that "we are never permitted to enter the male mind [and] we see George as his ladies see him and need him to be seen" (Welty, 1998, p. 57). The result, Mc Alpin clarifies, is that "the independence of George is to some degree within the familial desires forced upon him" (Welty, 1998, p.490). Donaldson concurs, by noticing that "[t]ime and time once more, female Fairchilds, from Cousin Laura to Ellen Fairchild, consider George and his significance to the family; but in any case, they might ask for George's essential part within the world of the Fairchilds, the viewpoint remains theirs. Eventually, the narrative's center gets to be the thoughts of those 
ladies who take for allowed George's centrality" (Welty, 1998, p. 5).

The women's development of masculinity sways between that can be characterized as essential or 'normalizing' points of view on manly personality. In specific, the development of George's identity as a legend depends on what can be named the fundamental truth of science. Dabney often refers to George's natural sweetness: "George and Denis were born sweet" and the women revere both (Welty, 1998, p. 125). She includes that George "the sweetest man in the Delta [. . . ] had an incorruptible, and hence unchallenging sweetness at heart" (Welty, 1998, p. 135). The establishing of manly character is hence to be found within the truth of a biological/innate/natural sweetness, Susan Donaldson recognizes that "George and his fellow Fairchild men are considered actors in history, inhabitants of the public arena, and their masculine legacy is that of a long line of Fairchild men killed in momentous events-ambushes, wars, fires, and duels" (Donaldson, 1997, p. 4).

Undoubtedly, after being raised under the law of the father, wedding at the command of her family, moving to her husband's domestic "to become a servant at the disposal of all family members," she worked in her husband's fields, procured water, looked after the livestock, took care of the home, bore the children and withstood her husband's beating if "he felt she was being disobedient or lazy towards him or his mother," (Welty, 1998, p. 11) The provincial lady carried her oppression inside her. She internalized it to such a level that she not required the typical update of the shroud to keep her in her place.

Masculine heroism is hence to be followed within "the truth of convention" through an offer to the reality of a masculine past inhabited with heroes. Particularly, "Denis, the Fairchild's valiant, and conveniently deceased, hero typifies the legendary southern gentleman upon which all the contemporary Fairchild men are modeled" (Tipton, 2013, p. 112). In both cases, since ladies push 
(ISSN : 2536 - 9555)

the normal sweetness of the southern heroes, as a result George enters a gallant position that has as of now been characterized in terms connected to Denis, heroism, perfect masculinity, etc. Welty's content appears to advance an essential definition of hegemonic manliness: one clear, settled, and true set of characteristics resistant to time that all southern heroes share.

A family just like the Abdulgawad's would have, no question, been touched by several changes. In spite of the fact that the family itself can be best characterized by its recognition of tradition based on the aspects religion instead of religion itself, Kammal is the character that displays the mainstream philosophy. This is often exemplified through Kammal's instructions. In considering and composing almost the logic of Bergson and the science of Darwin, two identities whose grant is an utter detestation to devout confidence, Kammal signals his flexibility from religion and the traditions based in it. On the other hand, George Fairchild (the southern male) peruses as another "oddly inverted heroic narrative," one that at the same works toward settling and unfixing manly personality at the same time. Certainly, Welty offers her readers a southern sentiment legend who ought to be imagined as a messianic legend and savior of society since "the attributes of divinity. . . will cling to the hero" of the romance" (Frye, 2000, p. 187).

Ellen, George's sister-in-law, thinks that "if it had never been for Denis, George might not have been completely the hero of this family- instead of sometimes almost its hero and sometimes almost its sacrificial beast" (Welty, 1998, p.151). In this occurrence, "heroism" (or perfect manliness) does not allude to the quality of a person's behavior, but to the needs of those labeling, naming, the person's behavior or making a securing of it, as proposed by the "its". By setting inside the same sentence two things (legend and mammoth) nearly resounding each other and by utilizing the "intensifier" sometimes twice, Welty recommends significant questions approximately southern manly character as substance or execution. The use of the word "sacrificial" alludes to men's have to be taken after a certain custom that limits their 
مجلة وادي النيل للاراسات والبحوث الإنسانية والاجتماعية والتربوية (مجلة علمية محكمة)

capacity to show, esteem, or indeed see other openings for themselves.

Palace Walk stands out fundamentally for its surprising exposé of Egyptian women's positions at the turn of the century. Hilary Kilpatrick presents four categories of Egyptian authors concurring to their treatment of ladies. The primary category incorporates authors who are not committed to the cause of ladies at all. Nearly all Middle easterner scholars of fiction earlier to the nineteenth century. The writers in this category are regularly more concerned with portraying the bigger political issues of their social orders, such as destitution, mass lack of education, debasement and bad form. These writers at that point regularly have small intrigued in bringing out the address of ladies or their freedom from Islamic and other conventional standards that ordinarily segregate against ladies. The moment gather incorporates what Kilpatrick calls "the conservative/traditional authors". (Kilpatrick, 1974, p. 128) These authors delineate ladies but as they were to fortify devout or conventional sex standards.

Consequently, Kehinde finds Mahfouz the traditional/ conservative and reformist categories of authors of Arabic fiction concerned with the issues of ladies. The traditional/ conservative author is characterized, concurring to Kehinde, by a conviction that "women's role in society is confined to the kitchen and other domestic chores, including procreation and childcare." (Kehinde, 2003, p.14) For Kehinde, Mahfouz's introduction of ladies takes on the conventional authentic frame. Most of his female characters show up quiet, respectful, patient and the sole attendant of custom and the domestic, setting him inside the traditionalist category. However, Mahfouz's novels too advance women's rights and consider "the key challenges facing gender equality and tolerance in his works." (Kehinde, 2003, p.16) This would then place him among the social reformists, who "understand the previous enslaved position of women and their ...struggle for freedom from 
(ISSN : 2536 - 9555)

the yoke of tradition and religion imposed on them by men." (Kehinde, 2003, p.17)

It ought to moreover be famous that in spite of the fact that Palace Walk is set against the foundation of anti-colonial change and records specific political uprisings in fastidious details, Mahfouz makes no specify of the practically equivalent to women's activist development taking place at the same time, nor does he recognize the thousands of ladies included within the antiBritish dissents he does archive. There are numerous minutes in Amina's and the other female character's lives in Palace Walk that highlight the circumstance of center course ladies in the turn of the century in Egypt.

Undoubtedly, Welty uncovers the degree to which any tradition can be built. In case of George's courageous character is clearly developed, it is developed in an arrangement of negatives, George existing for what or who he isn't (Denis) instead of what he really is. Eventually, Welty appears to question whether men like Denis or George got to be something or somebody at all: give up will as it was lead two ways: being a "hero" or getting to be a "sacrificial beast"- in each case, as the historical underpinnings of the word "hero" and "sacrificial beast" proposes, being a deliberation, but never a human being. George's predicament is to have yielded himself on the holy place of manliness and to have forgotten how to be a man, not essentially a noble man, in the event that not a "sweet boy" (Welty, 1998, p.195). Within the same vein, Denis's honor lies in how he died, instead of how he lived; as Lisa Cade Wieland declares, "the single most imperative thing that Denis did to attain legend. (Welty, 1998, p.9)

As John Alexander Allen focuses out, "the tendency of Eudora Welty's fiction is indeed anti-heroic; that is, it makes legitimate fun of the posturing male hero-adventurer" (Allen, 1994, Moments p. 255). In particular, and as James Wallace remarks, "George's rejection of patriarchal authority represents a conceptual subversion of the heroic masculine ideal, St. George" (Wallace, 2009, p. 56). Undoubtedly, in the event that the legend of St. 
مجلة وادي النيل للاراسات والبحوث الإنسانية والاجتماعية والتربوية (مجلة علمية محكمة)

George was for centuries used to propagate chivalry and patriarchal specialist, with George Fairchild, Welty gives an option to St. George's notorious hyper- masculine valor, "he cares nothing for preserving feminine sexuality; his passivity reverses St George's active pursuit of upholding Christian values, and his acceptance of others contrasts St George's violent enforcement of a hegemonic worldview" (Wallace, 2009, p. 56).

In Delta Wedding, the yellow Canine courageous scene too partakes within the subversion of a settled, fundamental, and characteristic sort of manliness: George's endeavors at sparing his mentally-challenged niece satirizes both male valor and the classic courageous situation, in which a courageous saint spares a lady from a beast or other unsafe risk, here a drawing nearer prepare. Welty modifies this situation to point out that ladies don't seek protection. She subverts the courageous scene in a number of ways: the rationally debilitated Maureen speaks to not one or the other a perfect lady in trouble nor a normal lad; George fizzled to oust her foot from the trestle, gave up his endeavors, and latently held up for the drawing nearer prepare, and the passing it involved; it was really Maureen that spared the two by pushing George who fell in reverse and pulled her down with him; and at last, the Yellow Puppy cannot speak to a genuine danger since it halted some time recently coming to the point where it would have hurt the combine. John Allen notes that because the train stopped, "the incident became officially... shorn of every trace of the tragic or heroic" (Allen, Demigods, 1983, p. 36).

Al-Sayyid Ahmed's patriarchal control is conjured through his control over ladies, particularly through the required females of secluding and veiling his female family individuals. The separation of these ladies, who epitomize the family riches by ethicalness of their family title and/or alliance, propose to the exterior world that the family is affluent, infers what is at stake in guaranteeing the female devotion and honor. The significance of separation to keep up family honor is in this way is brought into help when Amina 
مجلة وادي النيل للاراسات والبحوث الإنسانية والاجتماعية والتربوية (مجلة علمية محكمة)

(ISSN : 2536 - 9555)

opposes the fundamental preface of the rules of separation, goes out on her claim without either her husband or a grown-up bloodrelated male guardian and is subsequently expelled from the family house by her husband. It isn't essentially the act of resisting her husband that speaks to such an insult to his respect, but or maybe that she debilitates the family title and patrimony when she goes out into the manly domain unaccompanied by a man and without the approval of her husband.

exchange greetings and enjoy one of [al-Sayyid Ahmad's] pleasantries or witty sayings...his conversation had brilliant touches relating to the popular culture that he had absorbed...from reading the newspaper and befriending an elite group... [indeed] his native wit, graciousness, charm and status as a prosperous merchant qualified [alSayyid Ahmad] to associate with [this group] on an equal footing. (Mahfouz, 1991, p.24)

While uncovering that ideal masculinity could be a discourse that's clearly made, blessed, and once in a while challenged, such readings fall flat to clarify what would make George a saint and by differentiate, Troy, the undesired untouchable within the community. In the event that Dabney gets it from observing George look at a coasting butterfly, that "...he was different, somehow... It was very strange, but she had felt it" (Welty, 2004, p.121), why would George, if not as it were since Denis's death, be saint? In George's case, not one or the other distinction, not one or the other science or convention, can clarify what make the stuff of courage that ladies see in him.

In Palace Walk, the fear of fitnah that was postured by the obvious presence of ladies included a component of vested communal intrigued to the separation of ladies which was 
religiously authorized. A woman's unobtrusiveness is gathered to be protected by men who did so in arrange to watch the honor of their family, but ladies themselves were seen to bear a devout commitment to maintain their possess unobtrusiveness. A part of a woman's obligation was to avoid fitnah, to anticipate men from feeling stirred, for on the off chance that a man gotten into mischief as a result of excitement by a woman's physical nearness, she actually, was to fault. Besides, this was considered to be a woman's obligation, not fair toward her family, but also toward the society in general. Cairo, proposes that it is the responsibility of a lady not to cause devastation in society, she ought to go out of the house three times in her lifetime: when she weds; when her parents and husband pass away' and when she dies. Any contact between men and women was considered as possibly unsafe.

In their socialization of men and women, the medieval social orders of the Islamic world assumed that the genders are required to coexist. Nevertheless, men and women are supposed to be associated in endorsed ways. This was based on a philosophy that expected that ladies were seductresses and men were vulnerable to temptation. Based on a suspicion of their intrinsic capacities, men were concurred the duty to set limits for ladies, who were considered to be underneath them. Legal advisers based this presumption on the Quran verses that state: "men are a degree above women." (The Holy Quran 2:228) whereas medieval jurists accentuation on fitnah must influence state of mind toward other concepts relating to women's humanity, these discourses were not by any implies unique or elite to the social orders of that time.

Al-Sayyid Ahmad would be absent for a number of days, giving the family a long and much required respite from "their oppressively prim life" (Mahfouz, 1991, p.164). The ladies are particularly energized approximately the opportunity they would appreciate "safe from their guardian's eye," as "they would be able, in the event that they so wanted, to urge a blameless breath of new discuss. Khadija and Aisha wondered if they can go to [the 
(ISSN : 2536 - 9555)

neighbor's] house in the evening to spend an hour there having fun and amusing themselves" (Mahfouz, 1991, p.164). Amina, out of internalized accommodation to the law of her spouse, on the other hand, needs to form beyond any doubt that the family continues with its regular schedule. But even in this vein, "she was more concerned to keep from vexing [al-Sayyid Ahmad] than she was convinced that he was right to be so severe and stern" (Mahfouz, 1991, p.165).

Welty unequivocally problematizes the ideas of specialist, control, and patriarchy as the strong establishments that the Fairchilds have taken for granted. If this authority can be easily disposed of, it raises a question approximately that clear boundaries that the Fairchilds have built up between what is genuine and what is not, what is Fairchild and what is not, what is manly and what is not, what is resistant to alter and what is not. In addition, by recommending that Troy may pass as a persuading impersonation of Shelley's father, Welty smashes the sociallystratified arrange of the southern ranch, by uncovering that the "other" can pass (and perhaps perilously transgress) these clear-cut boundaries, actually as well as physically.

George Inevitably uncovers that the establishments that Shelley (re) erects to stand up to modern options are not exceptionally strong, which the Fairchild themselves exist in a world curbing the self, curbing each elective for otherness and eventually quelling history, alter, and clearly the obscure. To stand up to the stun of acknowledgements, one can discover asylum in contribute; to stand up to the conditional mode of a questionable future, the self-sufficient manor family favors to quit the subject and find asylum within the naturalism of men who are accepted to remain harmless "boys". Whereas the novel within the over occasion describes the inconsistencies included in what it implies to be seen as a saint and uncovers how different forms of southern masculinity are set as hegemonic, challenged, to setting the incongruent pressures emerging from such an ease of characters. 
Such examination of the status of George outlines how Welty seems to fit the (white) gendered built of the southern sentiment legend to divulge its intensity as well as the variety of the manly posture that men may be inquired to expect. Welty recommends that the labialization prepare or the category development is in emergency: manly personality is fixed at the same time because it is challenged. Men are numerous; masculinities are untrustworthy builds; bravery itself appears to be a progressively idea, uncovering how the fixity of the male saint on its platform is hence a matter of consistent creation. As Michael Kreyling clarifies, within the introduction of the yellow puppy scene, for occurrences, and in each telling of the crisis of the trestle, able to can "trace the different versions of masculinity being imposed on George [. . .] Aunt Tempe condones his self-sacrificial gesture as wholly appropriate to the male responsibilities of the Fairchild line" (Kreyling, Understanding 1987, p.115). Orrin's version, by contrast, "so blandly assumes George's actions to be natural as not to comment on them at all" (Kreyling, Understanding 1987, p. 94).

It is obvious from both al-Sayyid Ahmad's behavior and Amina's response that al-Sayyid Ahmad has all the control. His benefit as the family patriarch is compounded here by the included rights of the being the one wronged. His quiet talks and silence disturb Amina. She started inquiring herself once whether he still harbored few outrages. Uneasiness was picking her heart once more. The man was considering with such speed and concentration that he had to taste for anything else. It was not the kind of thought that develops at the goad of the minute. It was a sort of persistent, long- enduring that had remained with him for the past few days "since his discovery of Amina's outing." (Mahfouz, 1991, p.193) from this minute on, Amina gets it that her honor and the honor of her family would get subject to addressing.

After asking her to explain her deeds, Amina finds herself defenseless against his expected accusations. She quietly recognizes her botch as she plans herself for the resulting 
encounter: "What could she do now that she was the guilty person?" (Mahfouz, 1991, p.193). As a lady blameworthy of transgressing the laws of patriarchy, Amina has indeed less rights than she had had some time recently. when Al-sayyid Ahmed Abdulgawad afterward inquiries her round the inspiration behind this transgression, Amina concedes her faults: She whispered in troubled gasps:

I take refuge with God, sir. My error was a big one" [Al-Sayyid Ahmad asks] "How could you have committed such a grave error? ...Was it because I left town for a single day?" In a trembling voice, its tones swayed by the convulsions of her body, she replied, "I have committed an error. It is up to you to forgive me" [al-Sayyid Ahmad] shook his head fiercely as though saying, "There's no point trying to argue. (Mahfouz, 1991, p.193).

By examining into a manliness that's on a very basic level missing in substance, Welty advances what Jeffrey Weeks would title a "politics of difference" (Weeks, 1995, p.5) which subverts the soundness of organic categories- that is, the truth of science that ladies regularly conjure when putting George on the platform of valor. Welty places our perusing of masculinity as a place of insecurity. Undoubtedly, on the off chance that George's personality appears to be certified (or stabilized) through ceremonies (of honor and chivalry) that ward off and ensure against the control of the wild and the impure-that is against time and change-George's "true interior" (like Troy's genuine nature) intermittently breaks through the text's (or the women's voices) carefully controlled surface. . "[S]weetness," Dabney realizes, "could be the visible surface of profound depths - 
the surface of all the darkness that might frighten her" (Welty, 1998, p.125).

Here, Welty plays with the thought of quiet, utilizing it to uncover instead of conceal. It is, in fact, within the nonattendance of a long discourse, that George talks best. Keeping stories untold appears to be fizzled journeys: to detect a covered up, tricky truth, of course, isn't getting an extreme quintessence of masculinity either; very the opposite; "Uncle George's two words shot out like one bird, then beat about the walls, struck in the rooms upstairs," (Welty, 1998, p.191) as in case these two words as it were, at the exceptionally minute, seem murder Laura. In some cases, undoubtedly, George's profundities come back to the surface when "the kindest of them all, would say a deliberate wounding thing - as if in assurance that nothing further might then hurt you" (Welty, 1998, p.167). For George, this repressed-self gushes forth as "fierce energies, even heresies" (Welty, 1998, p.168).

\section{Conclusion:}

Family code and bonding are the bases of family and society which share the basic rules of any society. In Palace Walk and Delta Wedding, Mahfouz and Welty try to support and clarify the family bonding, and its impact on the unity of the family and the moral charter within society. In Palace Walk, Mahfouz tries to explain the hypocrisy of the hero who keeps his family united by imposing on them the laws and rules that he himself penetrates. On the other hand, Delta Wedding tries to explain how family events can bring the family together to show some of their qualities within society. Despite the differences in cultures, customs and traditions, the definition of the family remains the same through different societies and eras.

This paper shows existentialism as the framework of thinking and holding place in the society. Palace Walk shows three pictures of disappointments, suppression and the clashing needs of father- 
(ISSN : 2536 - 9555)

child connections that all contribute to existentialism. Besides, it incorporates numerous perspectives of existentialism through the thinking process of betrayal and disappointment of the hero who lives a twofold life. The motive of change, the rummage around the reality, despair, generational struggle, dissatisfaction, and betrayal are the subthemes that contribute to the concept of existentialism. Also, Delta Wedding is a sensitive and unconditional presentation of a family. The story, or may be the circumstances; since there's no cohesive plot, is seen mainly through the eyes of a young lady, Laura Mcraven, who comes to Fairchild for the marriage of her cousin Dabney Fairchild with the 'low-born northern Mississippian Troy Flavin, who works as a supervisor in Fairchild areas fields. The Fairchilds are a closelyknit family who squabble with each other, but display an invulnerable divider to untouchables; those who wed into the family must either acknowledge its ways and lose their personalities in it or be inferiors. The marvelous ancient house, full of sisters, close relatives and cousins is the center of a life of fascinatingly disorganized unpredictability; its installations incorporate a maniacal lady and a number of children.

\section{Works Cited:}

Allen, J. (1994). "Eudora Welty: The Three Moments." The Critical Response to Eudora Welty's Fiction. Ed. Laurie Champion. Westport, CT: Greenwood, 254-71. Print.

. (1983). "Demigods in Eudora Welty's Fiction." Eudora Welty, Thirteen Essays: Selected from Eudora Welty, Critical Essays. Ed. Peggy Whitman. Prenshaw. Jackson: UP of Mississippi, 26-56. Print.

Bouton, D. (2008). Eudora Welty's Delta Wedding. Amsterdam: Rodopi, Print. 
Masculinity and Family Bonding in Naguib Mahfouz's Palace Walk and Eudora Welty's Delta Wedding.

Dr. Shaimaa Mohamed Hassanin

مجلة وادي النيل للاراسات والبحوث الإنسانية والاجتماعية والتربوية (مجلة علمية محكمة)

Crews, E. (2012). The Role of the Home in Eudora Welty's Delta Wedding and the Optimist's Daughter. Diss. Georgia State U, Print.

Donaldson, V. (1997) "Gender and History in Eudora Welty's Delta Wedding." South Central Review 14.2: 3-14 ye, Northrop. Anatomy of Criticism. Princeton: Princeton UP, Print.

Dyer, R. (1991). Palace Sketches Portrait of the Artist. Boston Globe. February.

Frye, N. (2000). Anatomy of Criticism: Four Essays. Princeton, NJ: Princeton UP, Print.

Kehinde, A. (2003). "The contemporary Arabic novel as social history: urban decadence, politics and women in Naguib Mahfouz's fiction." Studies in the Humanities. Summer, Vol. 30. Issue $1,144$.

Kilpatrick, H. (1974). The Modern Egyptian Novel: A Study in Social Criticism. London: Ithaca Press for the Middle East Centre, St. Antony's College.

Kreyling, M. 1987). Figures of the Hero in Southern Narrative. Baton Rouge: Louisiana State UP, Print.

------. (1999). Understanding Eudora Welty. Columbia: U of South Carolina Press, Print.

Mahfouz, N. (2001). Naguib Mahfouz at Sidi Gaber: Reflections of a Nobel laureate, 1994-2001: from Conversations with Mohamed Salmawy. Cairo: The American University in Cairo Press; Chichester: Wiley.p.108.

(1991). Palace Walk. New York: First Anchor Books/ Doubleday, 37. 
(ISSN : 2536 - 9555)

McHaney, P. (2005). "Containment, Flux, and Flexibility in Delta Wedding: Dabney Fairchild's Gravidity." Ed. Géraldine Chouard and Danièle Pitavy. Eudora Welty and the Poetics of the Body. Rennes: Presses Universitaires De Rennes, 131-40. Print.

Miller, P. (2004). The Power of the Pleading Mask. Women and the Masculine Ideal in Eudora Welty's Delta Wedding. POMPA: Publications of the Mississippi Philological Association 54-56. Web.

Prenshaw, W. (1979). "Woman's World, Man's Place: The Fiction of Eudora Welty." Eudora Welty: A Form of Thanks. Ed. Cleanth Brooks, Ann J. Abadie, and Louis E. Dollarhide. Jackson: U of Mississippi, 46-77. Print.

Powell, L. (2007). Dispatches from the Homefront Eudora Welty's Delta Wedding. Diss. Print.

The Holy Quran. Trans. (1964). Arthur Arberry. Oxford: Oxford University Press, 2:228

Tipton, G. (2013): "He Doesn't Strike Me as a Family Man": Uncloseting George Fairchild's Queerness in Eudora Welty's Delta Wedding. Eudora Welty Review 5, 109-27.

Wallace, R. (2009). Taking Eudora Welty's Text out of the Closet Delta Wedding's George Fairchild and the Queering of Saint George. Diss. Georgia State U, Print.

Weeks, J. (1995). Invented Moralities: Sexual Values in an Age of Uncertainty. Cambridge, Eng.: Polity, Print.

Welty, E. (1998). Complete Novels. New York: Library of America, Print.

------. (1984). "Interview with Linda Kuehl: The Art of Fiction XL VII: Eudora Welty." Conversations with Eudora Welty. Ed. Eudora Welty and Peggy Whitman. Prenshaw. Jackson: UP of Mississippi, 74-92. Print. 